\title{
Direct Determination of Tetracycline Hydrochloride and the Interaction with Bovine Serum Albumin by UV Spectra in Water
}

\author{
Banan A. Akrawi Isam J. Al-Nuri Sana A. Hussin \\ Department of Chemistry/ College of Science/ University of Mosul
}

(Received 11 / 7 / 2013 ; Accepted 28 / 10 / 2013)

\begin{abstract}
The UV fourth order derivative spectra were selected as the more reliable technique for the direct quantification of pure Tetracycline Hydrochloride in water, after the measurement of the zero, first, second, third and fourth order spectra, within the concentration range at (0.2885144.27) $\mu \mathrm{g} / \mathrm{ml}$ with $\mathrm{R}^{2}=0.9998$ and $\mathrm{RSD}=0.215 \%$.

Bovine serum albumin was directly quantified by the fourth order UV derivative technique within the concentration range (6.7-2680) $\mu \mathrm{g} / \mathrm{ml}$ with $\mathrm{R}^{2}=0.9998$ and $\mathrm{RSD}=0.324 \%$. Appreciable interaction between Tetracycline hydrochloride and Bovine serum Albumin was found in accordance with the fraction coefficient and the apparent binding constant.

The UV-fourth order derivative technique appears to be in a good accuracy and precise method for the direct quantification of Tetracycline Hydrochloride and Bovine Serum Albumin (BSA) in water.
\end{abstract}

Keywords: Tetracycline hydrochloride, Bovine Serum Albumin, Direct quantification.

\section{القير المبالشر لتترلسايكلين هيدوكلورليد وتدلخلهمعمطل الالبومين ألقري بولملة الأشعةفوق البفسجية}

\section{الملخص}

يتضمن البحث ظبقطقريقة المشقة الرابعة للأشعة فوق البفنجية للقدير الكمي المبلثر، للتترلسايكلين هيدروكلورلي د

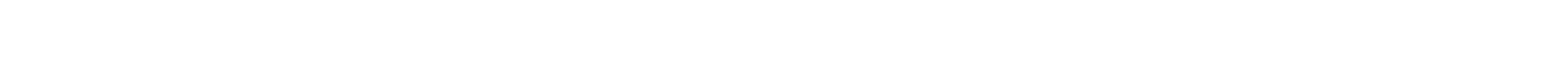

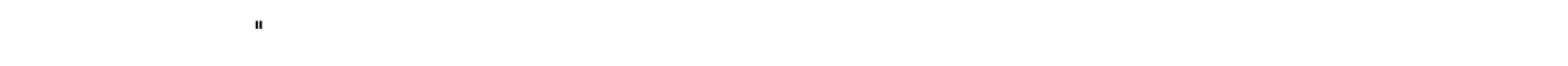

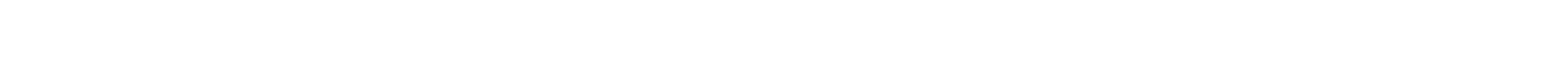

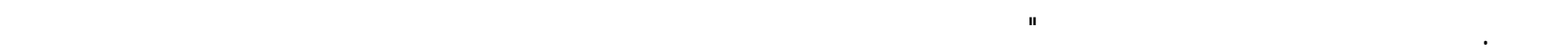

الكامل الدالة: تترلسايكلين هيدروكلورايد،مصل الالبومين ألقري، القيلس الكمي المبلثر.

INTRODUCTION

Tetracycline hydrochloride is a yellow crystalline powder, soluble in water and alcohol, its molecular formula is $\mathrm{C}_{22} \mathrm{H}_{24} \mathrm{~N}_{2} \mathrm{O}_{8}$. $\mathrm{HCl}$ and its structural formula is: 
<smiles>C[C@@]1(O)C(O)=C(C(N)=O)C(=O)[C@@]2(O)C(O)=C3C(=O)c4c(O)cccc4[C@](C)(O)[C@@H]3C[C@]12C</smiles>

\section{Tetracycline Hydrochloride \\ M.WT=480.9}

It is one of the tetracyclines antibiotics which treats numerous types of gram positive and gram negative bacteria (Navigation, 2005), (Katzung et al., 2009).

Various methods were used for the quantitative determination of tetracycline hydrochloride, spectroscopical method (Masawa et al., 2008), (Abdel Khalek et al., 1983), (Morelli and Peluso, 1985), (Sastry et al., 1996), (Al-Ramadani, 2007), HPLC methods (Ruengsitagoon, 2008), (Bhattacharya, 2003), (Reybroeck et al., 2007), (Fritz and Zuo, 2007), (Moats and Khan, 1996), (Bonta, 2007) and by mass spectrometry (Sczesny et al., 2003), (Jeon and Paeng, 2009).

This work aimed to show the direct determination of pure tetracycline hydrochloride in water, and to study their interactions with albumin by recording the fourth order derivative UV spectra in water at $\lambda=282 \mathrm{~nm}$ and $310^{\circ} \mathrm{K}$ with a good accuracy and precision and the results were compared with the standard pharmaceutical method.

\section{Material}

\section{EXPERIMENTAL}

Teracycline hydrochloride is supplied by the state company for drug industries and medical appliances in Nineveh, Iraq (N.D.I), and was used without any further purification. Bovine serum albumin is supplied by Fluka company.

\section{Preparation of stock solution:}

A stock solution of $(0.01 \mathrm{M})$ of pure tetracycline hydrochloride was prepared by dissolving $0.1202 \mathrm{~g}$ in $25 \mathrm{ml}$ distilled water. Other concentrations were prepared from this solution by proper dilution.

A stock solution of $(0.0001 \mathrm{M})$ of pure bovine serum albumin was prepared by dissolving (0.1675)g in $25 \mathrm{ml}$ distilled water. Other solutions were prepared from this solution by proper dilution with distilled water.

\section{Instrumentation}

The main spectra measurements were performed by a double beam Shimadzu UV-1800 (UVVisible) spectrophotometer connected to a computer with a Pentium 4 processor. The system is supplied with a temperature controller type Shimadzu TCC-240 A and TCC-240 CE, which is equipped with insulated constant temperature cell houses. The temperature deviation varied within the limits of $\pm 0.1{ }^{\circ} \mathrm{C}$. The optimized conditions for spectrophotometric measurement were derivative modes at scan speed fast, slit width $2 \mathrm{~nm}$. Derivative UV spectra were recorded over wavelength range (1100-190) $\mathrm{nm}$ using teflon stopper quartz cuvette with dimensions of $(1 \times 1 \times 4 \mathrm{~cm})$. Other used apparatus are mettler sartor us 2004 MP6 electronic semi-micro balance with five digits and Electrothermal melting point apparatus IA 9300. 


\section{RESULTS AND DISCUSSION}

The zero order UV spectrum of pure tetracycline hydrochloride solution in distilled water was measured against distilled water as a blank. The spectrum showed two bands at $276 \mathrm{~nm}$ with $\varepsilon_{\max }=15425$ lit.mol ${ }^{-1} . \mathrm{cm}^{-1}$ and another band at 356nm with $\varepsilon_{\max }=14925$ lit.mol ${ }^{-1} . \mathrm{cm}^{-1}$ Fig. (1).

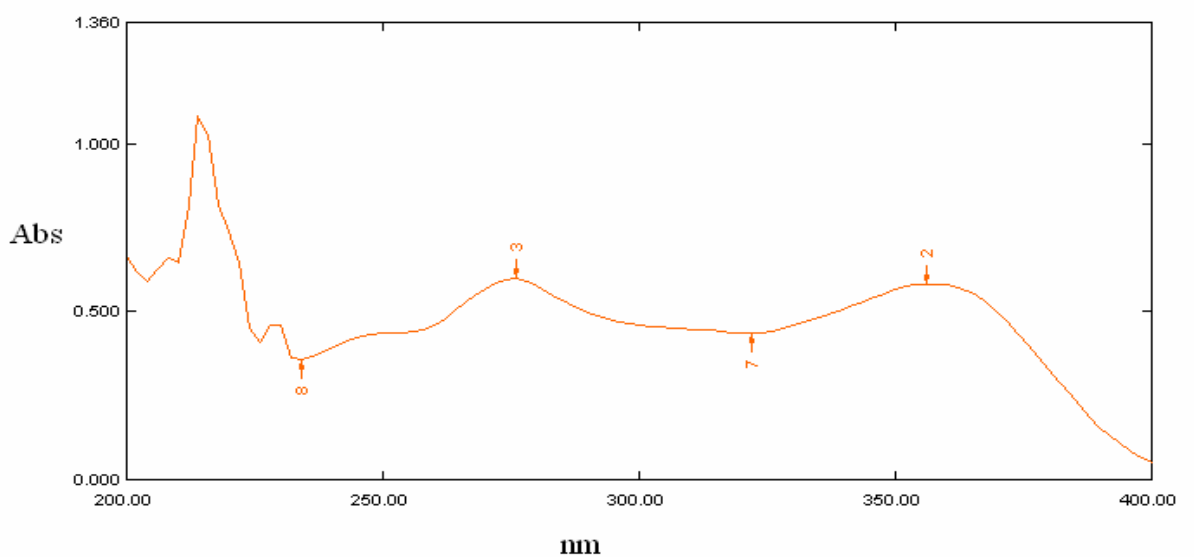

Fig. 1: UV-absorption of zero order spectra of $(19.236 \mu \mathrm{g} / \mathrm{ml})$ of pure tetracycline hydrochloride in water at $298.16^{\circ} \mathrm{K}$.

The effect of temperature and time on these spectra showed that ,there is no effect of temperature on the absorbance of pure tetracycline spectra in water within the temperature range (298.16-313.16 ${ }^{\circ} \mathrm{K}$ ) as shown in (Table 1 ).

Table 1: Temperature effect on the absorbance of pure tetracycline hydrochloride $(19.236 \mu \mathrm{g}$ $/ \mathrm{ml}$ ) in water at $\lambda_{\max } 356 \mathrm{~nm}$ and $298.16 \mathrm{~K}$.

\begin{tabular}{|c|c|c|c|c|c|}
\hline $\begin{array}{c}\text { Temperature } \\
{ }^{\circ} \mathbf{K}\end{array}$ & $\mathbf{2 9 8 . 1 6}$ & $\mathbf{3 0 3 . 1 6}$ & $\mathbf{3 0 8 . 1 6}$ & $\mathbf{3 1 0 . 1 6}$ & $\mathbf{3 1 3 . 1 6}$ \\
\hline Abs & 0.606 & 0.605 & 0.605 & 0.602 & 0.601 \\
\hline
\end{tabular}

The effect of time on the zero-order spectrum of tetracycline hydrochloride solution in water shows that the solution is stable up to more than 24 hours, as shown in (Table 2).

Table 2: Effect of time on the absorbance of pure tetracycline hydrochloride $(19.236 \mu \mathrm{g} / \mathrm{ml})$ in water at $\lambda_{\max } 356 \mathrm{~nm}$ and $298.16^{\circ} \mathrm{K}$.

\begin{tabular}{|c|c|c|c|c|c|c|c|c|c|}
\hline $\begin{array}{c}\text { Time } \\
\text { (min) }\end{array}$ & $\mathbf{5}$ & $\mathbf{1 5}$ & $\mathbf{2 5}$ & $\mathbf{3 5}$ & $\mathbf{5 0}$ & $\mathbf{6 0}$ & $\mathbf{9 0}$ & $\mathbf{1 2 0}$ & $\mathbf{2 4 h}$ \\
\hline Abs & 0.606 & 0.606 & 0.604 & 0.605 & 0.604 & 0.605 & 0.606 & 0.604 & 0.605 \\
\hline
\end{tabular}

The quantification of pure tetracycline hydrochloride in water was accomplished according to the absorbance at $\lambda_{\max }=356 \mathrm{~nm}$ and at $298.16^{\circ} \mathrm{K}$, for this purpose, the spectra of a series of different concentration solutions were recorded and the absorbance at $\lambda_{\max }=356 \mathrm{~nm}$ plotted versus the molar concentrations. The results showed a linear relationship obeying Beer's-Lambert law within the concentration range (0.385-48.090) $\mu \mathrm{g} / \mathrm{ml}, \mathrm{R}^{2}=0.9993$ and $\mathrm{RSD}=0.125$ Fig. (2), (Table 3). 


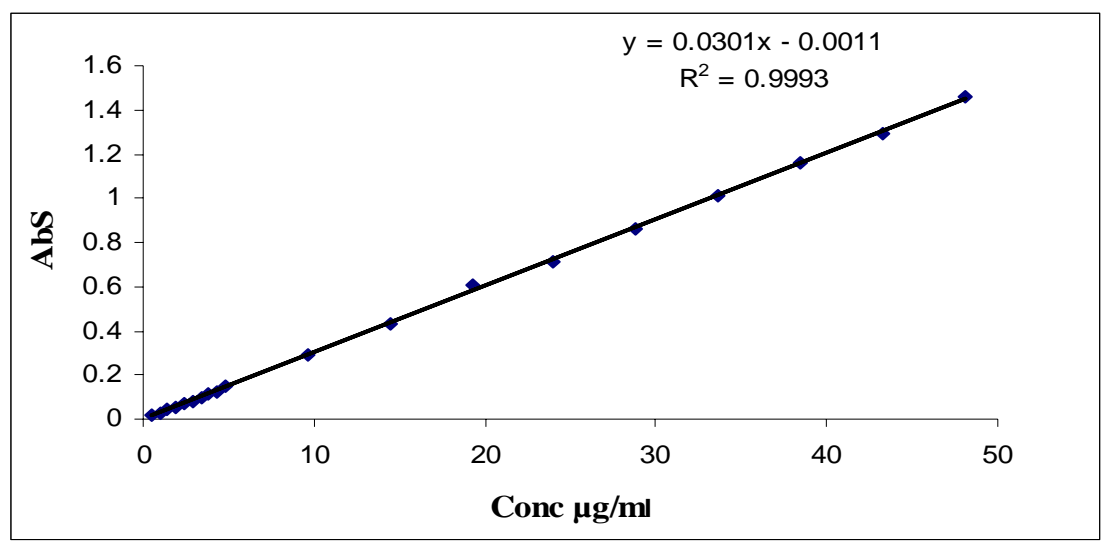

Fig. 2: Calibration curve of the zero order spectra of pure tetracycline hydrochloride solutions in water at $298.16^{\circ} \mathrm{K}$ and $356 \mathrm{~nm}$.

Table 3: Absorbance of the zero order spectra at $356 \mathrm{~nm}$ and $298.16{ }^{\circ} \mathrm{K}$ for different concentration solutions of pure tetracycline hydrochloride in water.

\begin{tabular}{|c|c|}
\hline Conc. $\boldsymbol{\mu g} / \mathbf{m l}$ & Abs \\
\hline 0.3847 & 0.012 \\
\hline 0.4809 & 0.015 \\
\hline 0.9618 & 0.027 \\
\hline 1.4427 & 0.041 \\
\hline 1.9236 & 0.056 \\
\hline 2.4045 & 0.069 \\
\hline 2.8854 & 0.083 \\
\hline 3.3663 & 0.098 \\
\hline 3.8472 & 0.112 \\
\hline 4.3281 & 0.127 \\
\hline 4.8090 & 0.150 \\
\hline 9.6180 & 0.292 \\
\hline 14.4270 & 0.436 \\
\hline 19.2360 & 0.582 \\
\hline 24.0450 & 0.710 \\
\hline 28.8540 & 0.861 \\
\hline 33.6630 & 1.008 \\
\hline 38.4720 & 1.159 \\
\hline 43.2810 & 1.297 \\
\hline 48.0900 & 1.458 \\
\hline
\end{tabular}

The first order derivatives UVspectra of tetracycline hydrochloride water solution were recorded for a series of solution of different concentrations $(0.385-144.270) \mu \mathrm{g} / \mathrm{ml}$. The spectra showed a positive peak at $\lambda=(238-276) \mathrm{nm}$ crossing the zero axis at $276 \mathrm{~nm}$ and a negative peak at $\lambda=(276-314) \mathrm{nm}$, and another positive peak at $\lambda=(314-356) \mathrm{nm}$ crossing the zero axis at $356 \mathrm{~nm}$ and a negative peak at $\lambda=(356-429) \mathrm{nm}$ Fig. (3). The positive peak at $\lambda=(314-356) \mathrm{nm}$ was chosen for the direct quantification of tetracycline by measuring the peak height of this peak for each solution and their plot versus the solution concentration. The results showed a straight line obeying Beer's -Lambert law within the range (0.385-48.090) $\mu \mathrm{g} / \mathrm{ml}$ with $\mathrm{R}^{2}=0.9999$ and $\mathrm{RSD}=0.381$, (Table 4), Fig. (4). 


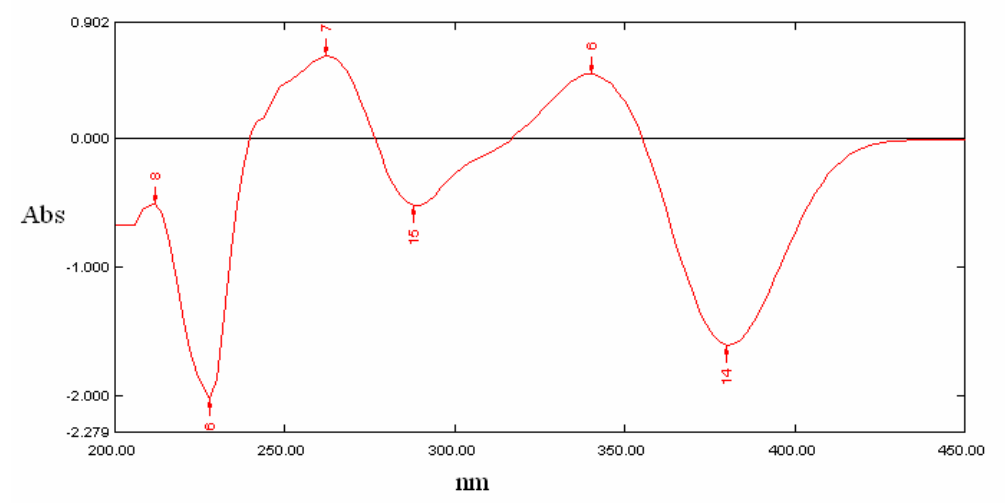

Fig. 3: UV -absorption of first order spectra of $(19.236 \mu \mathrm{g} / \mathrm{ml})$ of pure tetracycline hydrochloride in water at $298.16^{\circ} \mathrm{K}$.

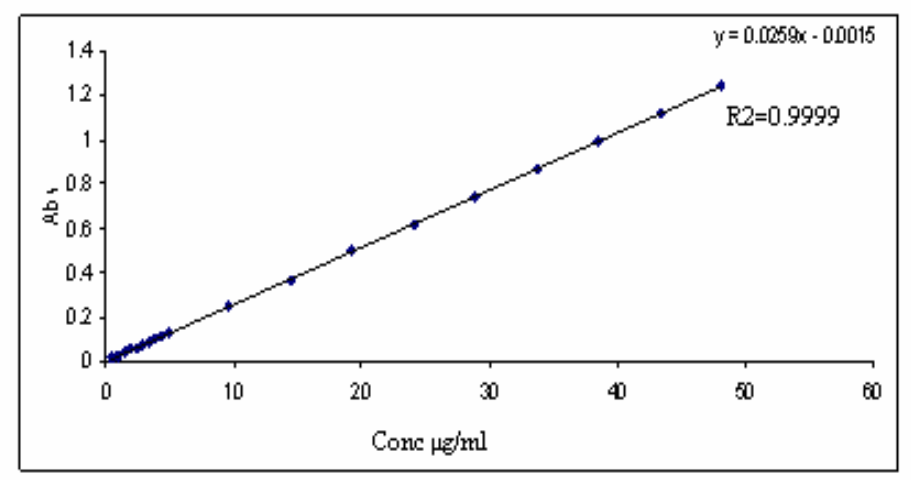

Fig. 4: Calibration curve of the first order derivative spectra of pure tetracycline hydrochloride for the positive peak at $\lambda=(340) \mathbf{n m}$.

Table 4: Absorbance measurement of the first order derivative spectra for the positive peak at $\lambda=(340) \mathrm{nm}$ for different concentration solutions of pure tetracycline hydrochloride.

\begin{tabular}{|c|c|}
\hline Conc $\boldsymbol{\mu g} / \mathbf{m l}$ & Abs \\
\hline 0.3847 & 0.012 \\
\hline 0.4809 & 0.013 \\
\hline 0.9618 & 0.022 \\
\hline 1.4427 & 0.037 \\
\hline 1.9236 & 0.050 \\
\hline 2.4045 & 0.060 \\
\hline 2.8854 & 0.071 \\
\hline 3.3663 & 0.083 \\
\hline 3.8472 & 0.097 \\
\hline 4.3281 & 0.112 \\
\hline 4.8090 & 0.128 \\
\hline 9.6180 & 0.250 \\
\hline 14.4270 & 0.364 \\
\hline 19.2360 & 0.501 \\
\hline 24.0450 & 0.611 \\
\hline 28.8540 & 0.741 \\
\hline 33.6630 & 0.869 \\
\hline 38.4720 & 0.995 \\
\hline 43.2810 & 1.118 \\
\hline 48.0900 & 1.250 \\
\hline
\end{tabular}


The second order derivative of tetracycline hydrochloride in water was recorded for a series of solutions of different concentrations ranging from $(0.192-96.180) \mu \mathrm{g} / \mathrm{ml}$. The spectrum shows two main negative peaks $\left(\lambda_{1}=274 \mathrm{~nm}\right)$ and $\left(\lambda_{2}=364 \mathrm{~nm}\right)$, with two satellites one at the both sides of each peak Fig. (5). The quantification was achieved according to the peak height at $(\lambda=364 \mathrm{~nm})$ which was estimated for each concentration of tetracycline solution in water. The plot of these absorbances versus the molar concentrations result in a straight line relation obeying Beer'sLambert law within the concentration range $(0.385-96.180) \mu \mathrm{g} / \mathrm{ml}$ with $\mathrm{R}^{2}=0.9998$ and $\mathrm{RSD}=0.593$ (Table 5), Fig. (6).

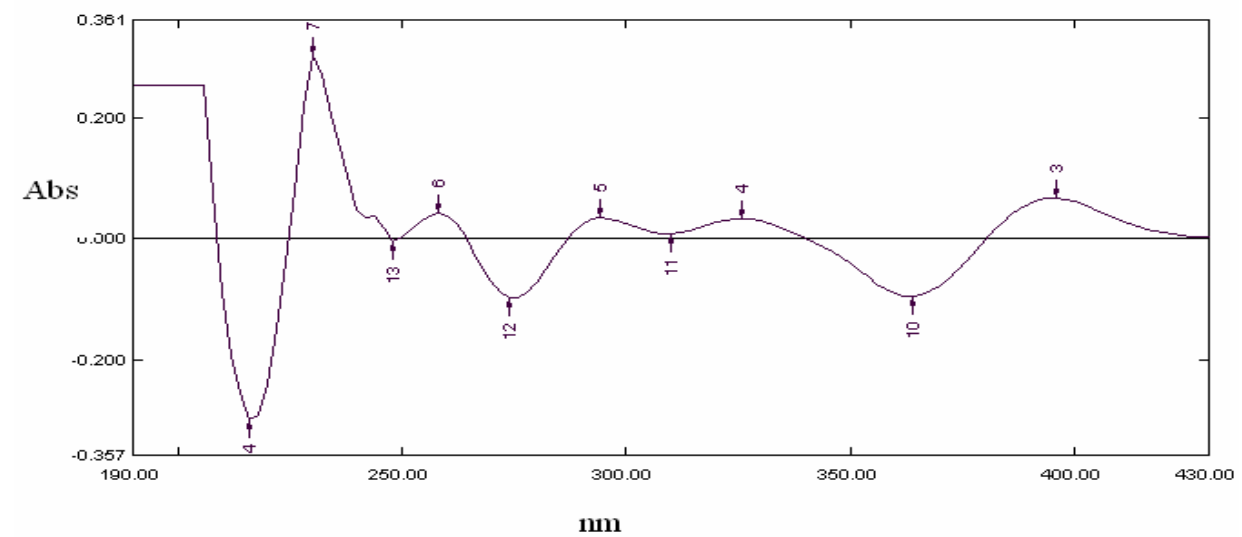

Fig. 5: UV -absorption of second order spectra of (19.236) $\mathrm{ug} / \mathrm{ml}$ of pure tetracycline hydrochloride in water at $298.16^{\circ} \mathrm{K}$.

Table 5: Absorbance measurement of the negative peak of the second order derivative spectra at $\left(\lambda_{\max }=364 \mathrm{~nm}\right)$ of pure tetracyclin hydrochloride.

\begin{tabular}{|c|c|}
\hline Conc $\boldsymbol{\mu g} / \mathbf{m l}$ & Abs \\
\hline 0.3847 & 0.002 \\
\hline 0.4809 & 0.002 \\
\hline 0.9618 & 0.004 \\
\hline 1.4427 & 0.007 \\
\hline 1.9236 & 0.009 \\
\hline 2.4045 & 0.011 \\
\hline 2.8854 & 0.014 \\
\hline 3.3663 & 0.016 \\
\hline 3.8472 & 0.018 \\
\hline 4.3281 & 0.021 \\
\hline 4.8090 & 0.024 \\
\hline 9.6180 & 0.047 \\
\hline 14.4270 & 0.071 \\
\hline 19.2360 & 0.095 \\
\hline 24.0450 & 0.116 \\
\hline 28.8540 & 0.140 \\
\hline 33.6630 & 0.164 \\
\hline 38.4720 & 0.190 \\
\hline 43.2810 & 0.211 \\
\hline 48.0900 & 0.235 \\
\hline 96.1800 & 0.509 \\
\hline
\end{tabular}




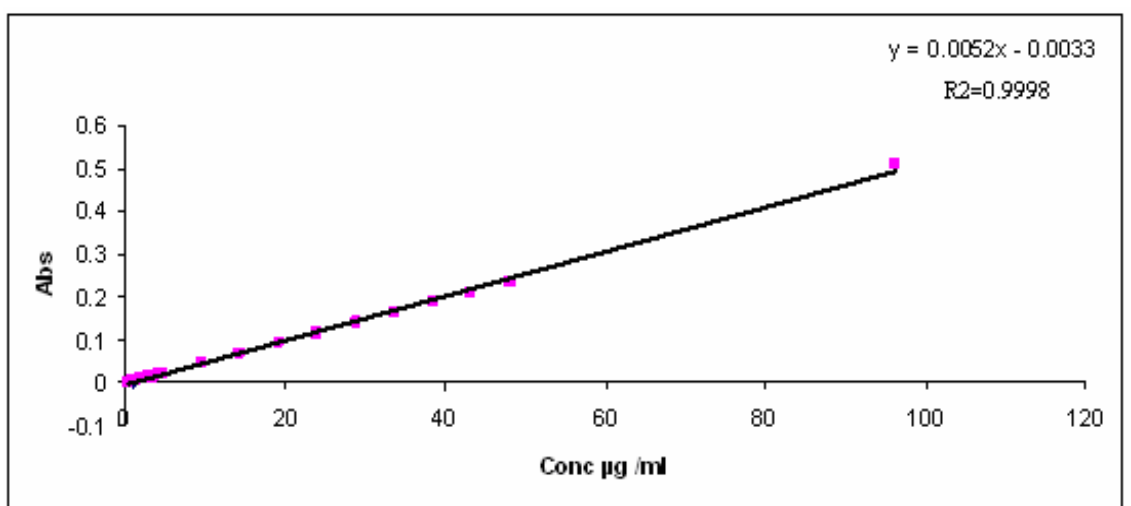

Fig. 6: Calibration curve of the second order derivative spectra of pure tetracycline hydrochloride solutions in water at $298.16^{\circ} \mathrm{K}$ and $364 \mathrm{~nm}$.

The third order derivatives UV spectra were recorded for a series of different concentrations of tetracycline hydrochloride in water. The spectrum consists of a negative peak in the region (258274) $\mathrm{nm}$ crossing the zero axis at $274 \mathrm{~nm}$ and a positive peak at (274-292) nm, and a second negative peak at (338-364) $\mathrm{nm}$ crossing the zero axis at $\lambda=364 \mathrm{~nm}$ and a positive peak at $\lambda=(364$ 393) nm Fig. (7). The quantification of tetracycline was accomplished according to the positive peak at $\lambda=(364-393) \mathrm{nm}$ through the estimation of their peak height and their plot against the concentration which results in a straight line relation obeying Beer's-Lambert law within the range (0.385-48.090) $\mu \mathrm{g} / \mathrm{ml}$ with $\mathrm{R}^{2}=0.9995$ and $\mathrm{RSD}=0.612$, Table (6), Fig. (8).

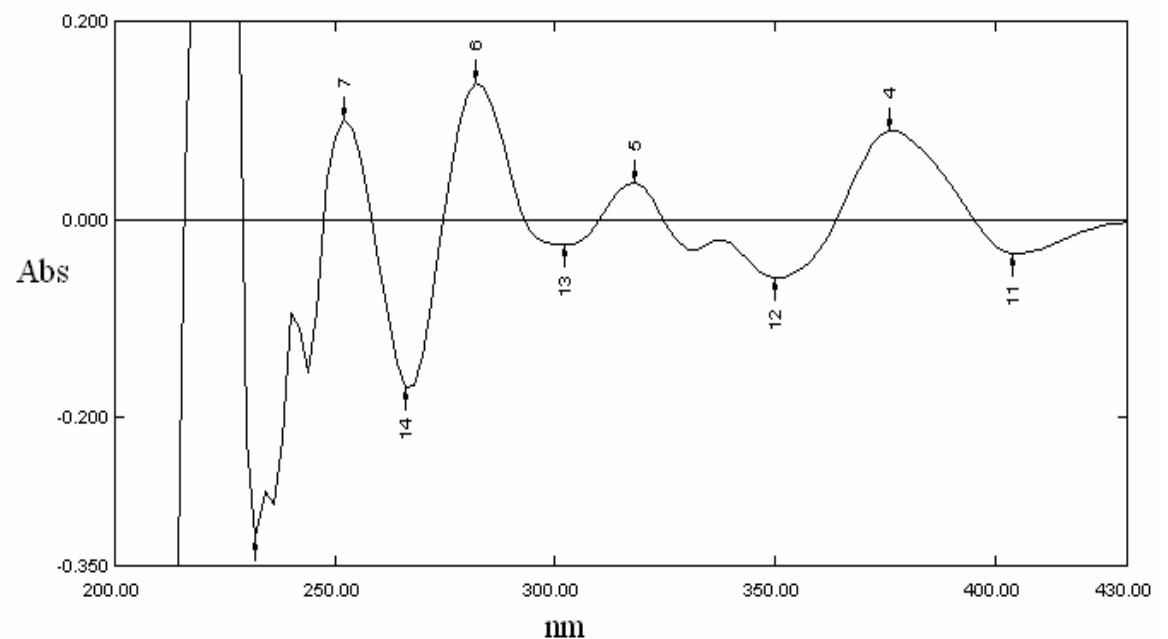

Fig. 7: UV -absorption of the third order spectra of (19.236 ) $\mathrm{ug} / \mathrm{ml}$ of pure tetracycline hydrochloride in water at $298.16^{\circ} \mathrm{K}$. 
Table 6: Absorbance of the positive peak of the third order derivative spectra at $\lambda=377 \mathbf{~ n m}$ of pure tetracycline hydrochloride in water at $\left(298.16{ }^{\circ} \mathrm{K}\right)$.

\begin{tabular}{|c|c|}
\hline Conc (ppm)pg/ml & Abs \\
\hline 0.3847 & 0.002 \\
\hline 0.4809 & 0.002 \\
\hline 0.9618 & 0.004 \\
\hline 1.4427 & 0.007 \\
\hline 1.9236 & 0.009 \\
\hline 2.4045 & 0.010 \\
\hline 2.8854 & 0.013 \\
\hline 3.3663 & 0.015 \\
\hline 3.8472 & 0.017 \\
\hline 4.3281 & 0.019 \\
\hline 4.8090 & 0.023 \\
\hline 9.6180 & 0.045 \\
\hline 14.4270 & 0.067 \\
\hline 19.2360 & 0.088 \\
\hline 24.0450 & 0.108 \\
\hline 28.8540 & 0.129 \\
\hline 33.6630 & 0.153 \\
\hline 38.4720 & 0.174 \\
\hline 43.2810 & 0.190 \\
\hline 48.0900 & 0.213 \\
\hline
\end{tabular}

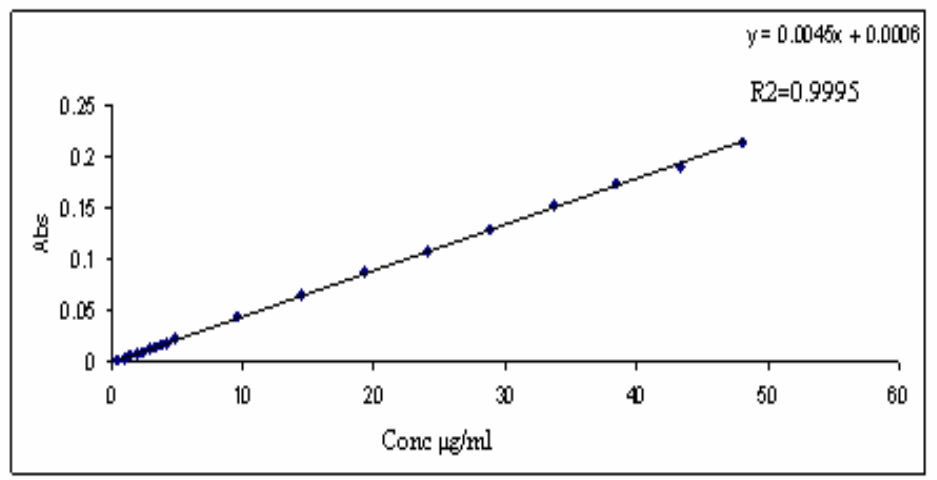

Fig. 8: Calibration curve of the third order derivative spectra of pure tetracycline hydrochloride solutions at $\lambda_{\max } 377 \mathrm{~nm}$ in water and $298.16^{\circ} \mathrm{K}$.

The fourth order derivatives UV spectra of pure tetracycline hydrochloride in water were recorded for a series of different concentrations. The spectrum showed two main positive peaks at $\lambda=274 \mathrm{~nm}$ and $\lambda=368 \mathrm{~nm}$ with two satellites at both sides of each peak Fig. (9). The quantification was accomplished according to the peak height at $\lambda=368 \mathrm{~nm}$ which was plotted versus the concentrations and resulted in a straight line relation obeying Beer's-Lambert law within the concentration range of $(0.289-144.270) \mu \mathrm{g} / \mathrm{ml}$ with $\mathrm{R}^{2}=0.9998$ and $\mathrm{RSD}=0.215$, (Table 7), Fig. (10). 


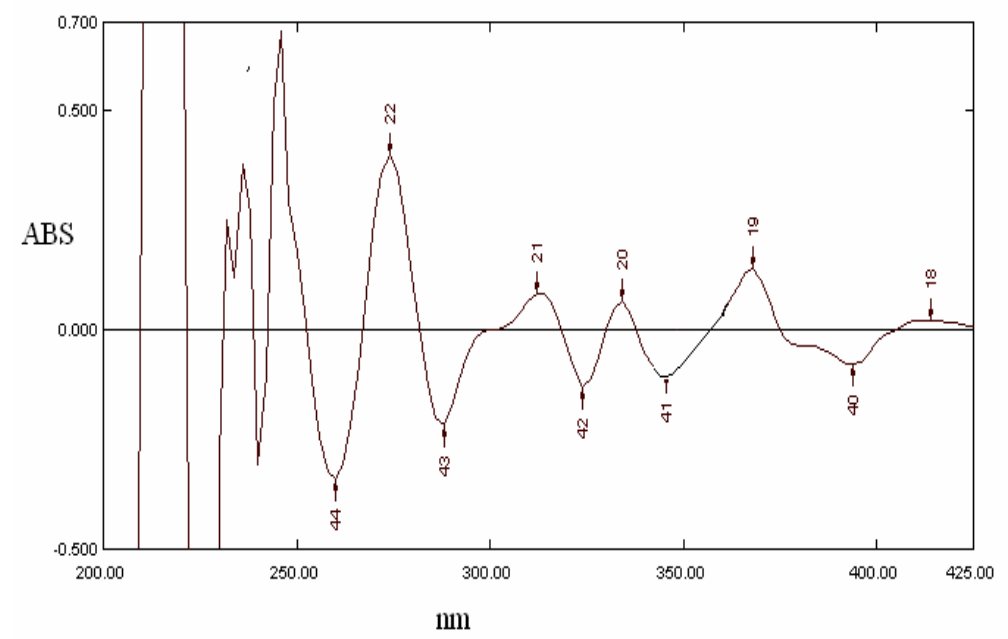

Fig. 9: UV -absorption of fourth order derivative spectra of (19.236) $\mu \mathrm{gg} / \mathrm{ml}$ of pure tetracycline hydrochloride in water at $298.16^{\circ} \mathrm{K}$.

Table 7: Absorbance measurement of the positive peak of the fourth order derivative spectra at $\lambda 368 \mathrm{~nm}$ of pure tetracycline hydrochloride.

\begin{tabular}{|c|c|}
\hline Conc $\boldsymbol{\mu g} / \mathbf{m l}$ & AbS \\
\hline 0.2885 & 0.004 \\
\hline 0.3847 & 0.005 \\
\hline 0.4809 & 0.006 \\
\hline 0.9618 & 0.011 \\
\hline 1.4427 & 0.013 \\
\hline 1.9236 & 0.016 \\
\hline 2.4045 & 0.017 \\
\hline 2.8854 & 0.022 \\
\hline 3.3663 & 0.024 \\
\hline 3.8472 & 0.029 \\
\hline 4.3281 & 0.032 \\
\hline 4.8090 & 0.038 \\
\hline 9.6180 & 0.092 \\
\hline 14.4270 & 0.141 \\
\hline 19.2360 & 0.162 \\
\hline 24.0450 & 0.190 \\
\hline 28.8540 & 0.250 \\
\hline 33.6630 & 0.300 \\
\hline 38.4720 & 0.345 \\
\hline 43.2810 & 0.385 \\
\hline 48.0900 & 0.440 \\
\hline 96.1800 & 0.880 \\
\hline 144.2700 & 1.331 \\
\hline & \\
\hline
\end{tabular}




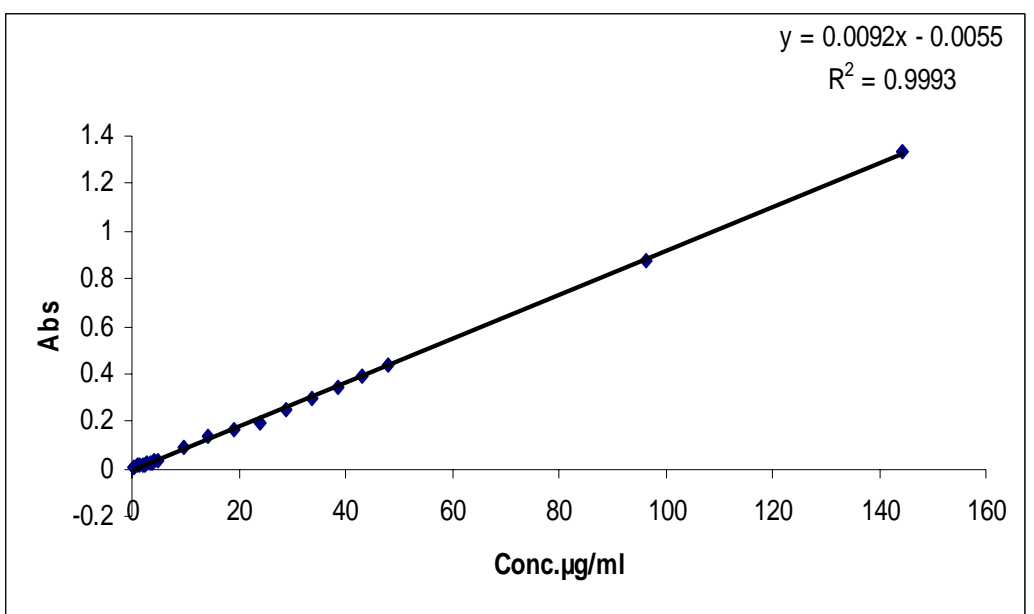

Fig. 10: UV -absorption of fourth order spectra of (19.236) $\mu \mathrm{g} / \mathrm{ml}$ of tetracycline hydrochloride in water at $298.16^{\circ} \mathrm{K}$ at $368 \mathrm{~nm}$ in water.

According to the results obtained, it is obvious that the fourth order derivative UV technique is the more reliable technique for the direct quantification of pure tetracycline hydrochloride in water, due to their measurable larger range of concentration.

For the examination of the accuracy and precision of the fourth order derivative technique for the quantification of pure tetracycline hydrochloride in water, the absorbance of three samples at three different concentrations were measured at $\lambda=368 \mathrm{~nm}$ and the results reveal a good accuracy and precision as show in Table (8).

Table 8: Accuracy and precision of the fourth order derivative spectra (at $368 \mathrm{~nm}$ ) for the determination of pure tetracycline hydrochloride in water.

\begin{tabular}{|c|c|c|c|}
\hline \multicolumn{2}{|c|}{ Concentration of tetracycline hydrochloride $\mathbf{\mu g} / \mathbf{m l}$} & \multirow{2}{*}{ Recovery \% } & \multirow{2}{*}{ Error $\%$} \\
\hline Taken & Found & & \\
\hline 2.40 & 2.44 & 101.6 & +1.6 \\
\hline 38.47 & 38.09 & 99.0 & -1.0 \\
\hline 96.18 & 96.25 & 100 & 0.0 \\
\hline
\end{tabular}

Bovine Serum Albumin (BSA):

The zero order UV spectrum of BSA in distilled water showed a peak at $\lambda_{\max }=278 \mathrm{~nm}$ with $\varepsilon_{\text {max }}=43325$ lit.mol ${ }^{-1} \cdot \mathrm{cm}^{-1}$. The absorbance values measured at this wavelength remain unchanged for more than 2hours within a temperatures range $298.16-313.16^{\circ} \mathrm{K}$ Tables (9 and 10).

Table 9: Effect of time on the absorbance of (BSA)(2680) $\mu \mathrm{g} / \mathrm{ml}$ at $\lambda=278 \mathrm{~nm}$ In water

\begin{tabular}{|c|c|c|c|c|c|c|c|c|c|}
\hline $\begin{array}{c}\text { Time } \\
\text { (min) }\end{array}$ & $\mathbf{5}$ & $\mathbf{1 0}$ & $\mathbf{1 5}$ & $\mathbf{2 5}$ & $\mathbf{3 5}$ & $\mathbf{5 0}$ & $\mathbf{6 0}$ & $\mathbf{9 0}$ & $\mathbf{1 2 0}$ \\
\hline Abs & 1.72 & 1.72 & 1.716 & 1.718 & 1.714 & 1.713 & 1.715 & 1.716 & 1.716 \\
\hline
\end{tabular}


Table 10: Effect of temperature on the absorbance of bovine serum albumin solution in water (2680) $\mu \mathrm{g} / \mathrm{ml}$ at $278 \mathrm{~nm}$.

\begin{tabular}{|c|l|l|l|l|l|}
\hline Temperature. $\mathbf{K}^{\circ}$ & $\mathbf{2 9 8 . 1 6}$ & $\mathbf{3 0 3 . 1 6}$ & $\mathbf{3 0 8 . 1 6}$ & $\mathbf{3 1 0 . 1 6}$ & $\mathbf{3 1 3 . 1 6}$ \\
\hline Abs & 1.751 & 1.751 & 1.745 & 1.744 & 1.746 \\
\hline
\end{tabular}

The fourth order derivative spectrum of BSA in water showed a main positive peak at $\lambda=282 \mathrm{~nm}$ with two satallites at each side of the peak. The peak height of the band at $\lambda=282 \mathrm{~nm}$ was measured for a series of different concentration solutions of pure BSA in water and plotted versus the concentration. The result is linear relation obeying Beer's -Lambert law within a concentration range $(6.7-2680) \mu \mathrm{g} / \mathrm{ml}$ with $\mathrm{R}^{2}=0.9998$ and $\mathrm{RSD}=0.0836 \%$ (Table 11), Fig. $(11,12)$.

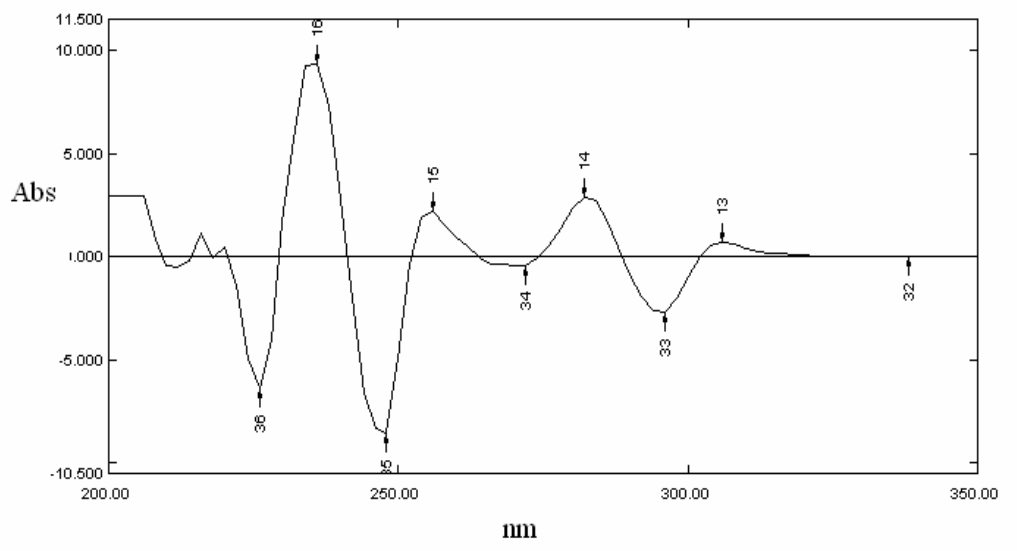

Fig. 11: UV -absorption of fourth order spectra of (2680) $\mu \mathrm{g} / \mathrm{ml}$ of pure (BSA)in water at $298.16^{\circ} \mathrm{K}$.

Table 11: Absorbance measurement of the positive peak of the fourth order derivative spectra at $\lambda_{\max } 282 \mathrm{~nm}$ of pure (BSA).

\begin{tabular}{|c|c|}
\hline Conc $\mathbf{~ g} / \mathbf{m l}$ & AbS \\
\hline 6.7 & 0.0077 \\
\hline 13.4 & 0.0130 \\
\hline 20.1 & 0.0204 \\
\hline 26.8 & 0.0271 \\
\hline 33.5 & 0.0356 \\
\hline 40.2 & 0.0407 \\
\hline 53.6 & 0.0560 \\
\hline 60.3 & 0.0608 \\
\hline 67.0 & 0.0711 \\
\hline 134.0 & 0.1395 \\
\hline 201.0 & 0.2099 \\
\hline 268.0 & 0.281 \\
\hline 335.0 & 0.3491 \\
\hline 402.0 & 0.4179 \\
\hline 469.0 & 0.4939 \\
\hline 536.0 & 0.5653 \\
\hline 603.0 & 0.6351 \\
\hline 670.0 & 0.7474 \\
\hline 1340.0 & 1.4363 \\
\hline 2010.0 & 2.1657 \\
\hline 2680.0 & 2.8506 \\
\hline
\end{tabular}




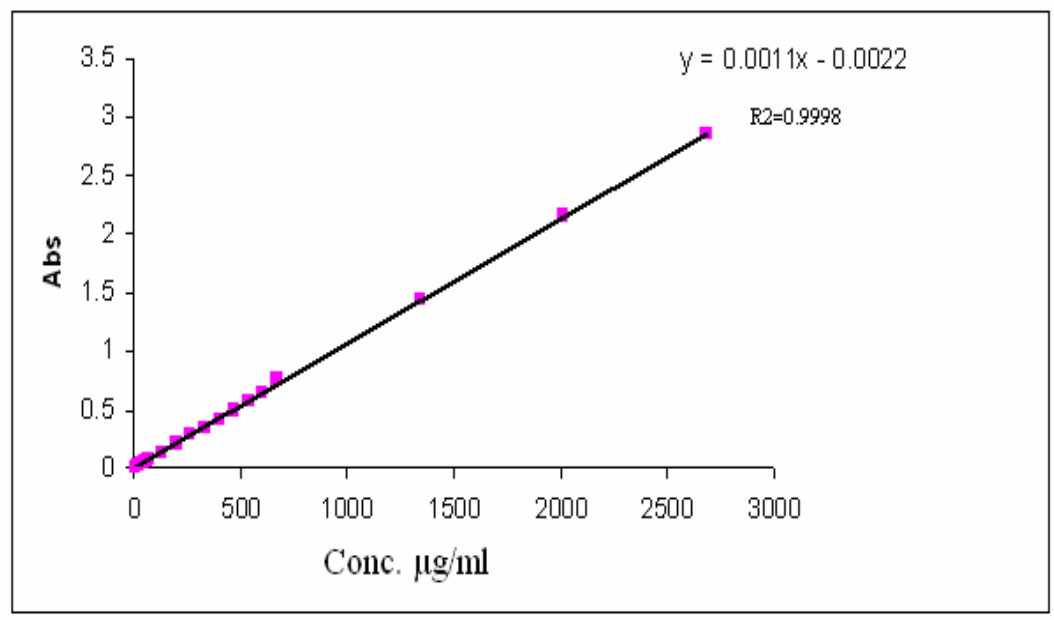

Fig. 12: Calibration curve of the fourth order derivative spectra of pure (BSA) solutions in water.

The accuracy and precision of the quantification of BSA in water was accomplished by the measurement of the peak height at $\lambda=282 \mathrm{~nm}$ of three samples at different concentrations of accurately prepared solutions, which indicate a good accuracy and precision for this method, (Table 12).

Table 12: Accuracy and precision of the fourth order derivative spectra at $\lambda=282 \mathrm{~nm}$ of the determination of pure ( BSA).

\begin{tabular}{|c|c|c|c|}
\hline \multicolumn{2}{|c|}{ Concentration of bovin serum albumin $\boldsymbol{\mu g} / \mathbf{m l}$} & \multirow{2}{*}{ Recovery \% } & Error \% \\
\hline Taken & Found & 99.38 & -0.62 \\
\hline 26.80 & 26.63 & 99.45 & -0.55 \\
\hline 67.00 & 66.63 & 101.70 & +1.30 \\
\hline 670.00 & 681.45 & &
\end{tabular}

The interaction of pure tetracycline hydrochloride with BSA :

The addition of successive amount of pure tetracycline hydrochloride in water of concentration $\left(9 \times 10^{-5}\right) \mathrm{M}$ to a solution of (BSA $)\left(1 \times 10^{-5} \mathrm{M}\right)$ in water, causes a gradual decrease in the measured absorbance at $\lambda=282 \mathrm{~nm}$ Table (13). 
Table 13: Absorbance after the addition of Tetracyclin Hydrochloride $9 \times 10^{-5} \mathrm{M}$ to (BSA) $1 \times 10^{-5} \mathrm{M}$ in water at $\mathrm{T}=310.16^{\circ} \mathrm{K}$ and $\lambda=282 \mathrm{~nm}$

\begin{tabular}{|c|c|c|c|c|}
\hline Conc (TCH) mol/L & Abs $\lambda=\mathbf{2 8 2} \mathbf{~ n m}$ & A/A & log1/ $\mathbf{T C H}]$ & logA/(A。-A) \\
\hline 0 & 0.7280 & 1 & & \\
\hline $5.96026 \mathrm{E}-07$ & 0.7190 & 0.987637 & & \\
\hline $8.91089 \mathrm{E}-07$ & 0.7100 & 0.975275 & & \\
\hline $1.18421 \mathrm{E}-06$ & 0.7140 & 0.980769 & 5.926571083 & 1.707 \\
\hline $1.47541 \mathrm{E}-06$ & 0.7080 & 0.972527 & 5.831087326 & 1.549 \\
\hline $1.76471 \mathrm{E}-06$ & 0.7070 & 0.971154 & 5.753327667 & 1.527 \\
\hline $2.05212 \mathrm{E}-06$ & 0.7050 & 0.968407 & 5.687797826 & 1.486 \\
\hline $2.33766 \mathrm{E}-06$ & 0.6990 & 0.960165 & 5.63121822 & 1.382 \\
\hline $2.62136 \mathrm{E}-06$ & 0.6970 & 0.957418 & 5.581473461 & 1.351 \\
\hline $2.90323 \mathrm{E}-06$ & 0.6960 & 0.956044 & 5.537119184 & 1.337 \\
\hline $3.46154 \mathrm{E}-06$ & 0.6920 & 0.950549 & 5.460730839 & 1.283 \\
\hline $4.28571 \mathrm{E}-06$ & 0.6870 & 0.943681 & 5.367976785 & 1.224 \\
\hline 0.000005625 & 0.6726 & 0.923901 & 5.249877473 & 1.084 \\
\hline $6.92308 \mathrm{E}-06$ & 0.6598 & 0.906319 & 5.159700843 & 0.985 \\
\hline $8.18182 \mathrm{E}-06$ & 0.6512 & 0.894505 & 5.087150176 & 0.928 \\
\hline $9.40299 \mathrm{E}-06$ & 0.6390 & 0.877747 & 5.026734253 & 0.856 \\
\hline $1.17391 \mathrm{E}-05$ & 0.6340 & 0.870879 & 4.930364072 & 0.828 \\
\hline $1.28571 \mathrm{E}-05$ & 0.6330 & 0.869505 & 4.890855531 & 0.823 \\
\hline Fractional coefficient( $\mathrm{k})$ & 0.88 & & & \\
\hline binding constant (K) & $9.772 X 10^{3} \mathrm{M}^{-1}$ & & & \\
\hline
\end{tabular}

BSA + Tetracycline hydrochloride $\longleftrightarrow$ BSA - Tetracyclin Hydrocloride

In order to highlight the nature of interaction between the Tetracycline Hydrochloride and BSA in water, The fraction coefficient $k$ was estimated by the plot of $\frac{A}{A_{0}}$ versus the concentration of the added Tetracycline Hydrochloride $\left(9 \times 10^{-5} \mathrm{M}\right)$. To BSA of concentration ( $\left.1 \times 10-5 \mathrm{M}\right)$ Fig. (13).

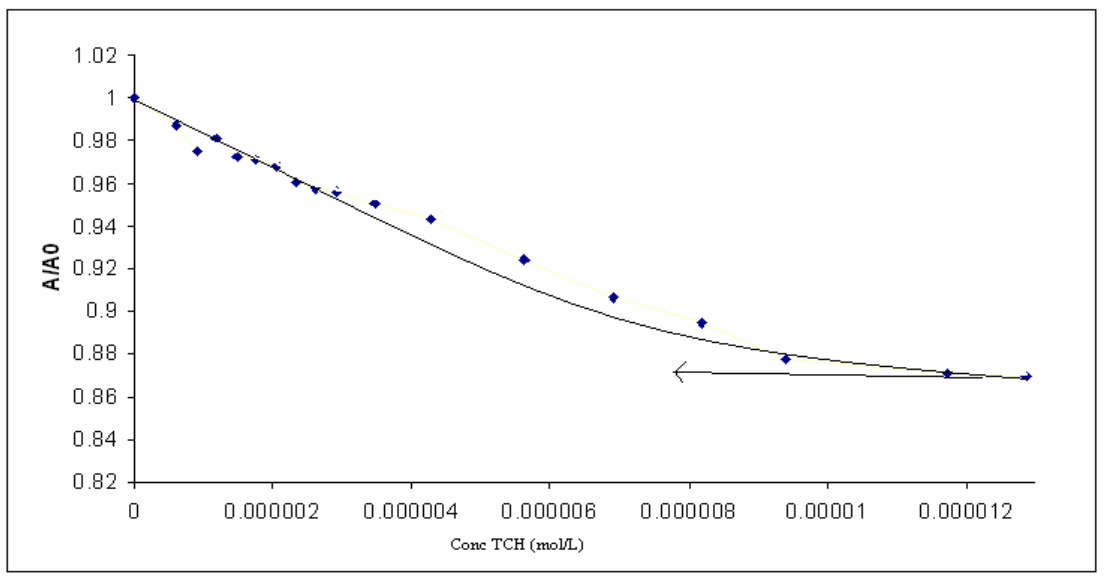

Fig. 13: Dependence on $\mathrm{A} / \mathrm{A}$ 。 ratio with addition of tetracycline chloride at fixed $\mathrm{BSA}\left(1 \mathrm{X10}{ }^{-}\right.$ $\left.{ }^{5} \mathrm{M}\right)$ at $310 \mathrm{~K}$. 
From which the fraction coefficient $\mathrm{k}=\frac{A}{A_{\mathrm{o}}}$ was estimated. The equation for voltammatric determination can be deduced according to absorbance equation as described below:

$$
\log \left(\frac{1}{\operatorname{Conc}[T C H](M)}\right)=\log K+\log \left(\frac{A}{A \circ-A}\right)
$$

Where $\mathrm{K}$ is the apparent binding constant, $\mathrm{A} \circ$ is the absorbance at $\lambda=282 \mathrm{~nm}$ before the addition of tetracycline hydrochloride, A the absorbance after each addition under the assumption of reversible complex of (BSA - Tetracycline hydrochloride) is 1:1 association complex. Then the plot of $\log (1 / \mathrm{conc}[\mathrm{TCH}])$ versus $\log (\mathrm{A} / \mathrm{A} \circ \mathrm{A})$ result in a linear relation with the intercept of log K, Fig. (14), from which the $\mathrm{K}$ value $=9.772 \times 10^{3}$ was calculated indicated that an appreciable interaction between BSA and tetracycline hydrochloride do exist.

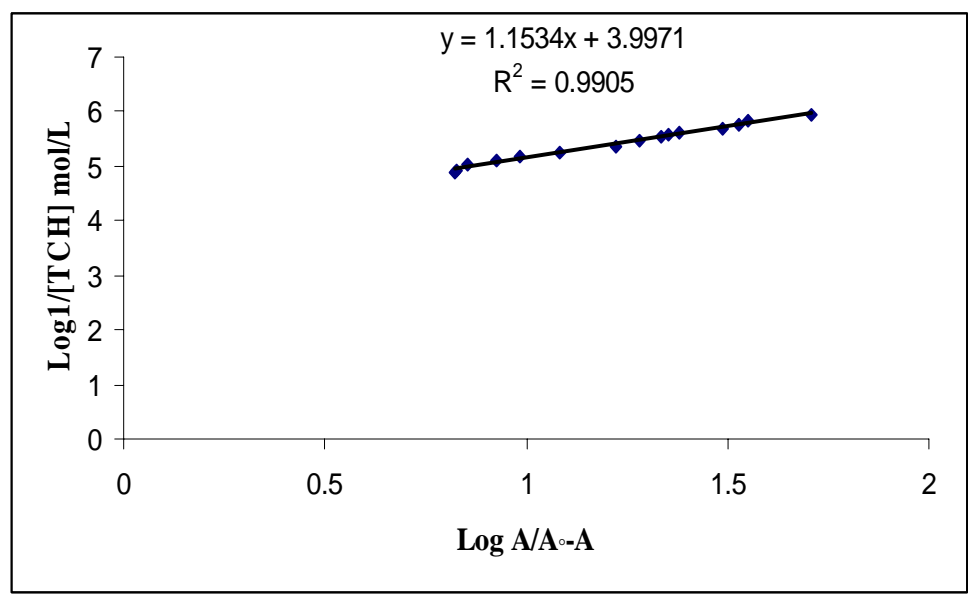

Fig. 14: Plot of $\log 1 /[T C H]$ versus $\log A /(A \circ-A)$ at fixed BSA $0.00001 M$ at $310^{\circ} \mathrm{K}$.

Determination of tetracycline hydrochloride by standard method (HPLC): ${ }^{\text {(B.P 2009) }}$

The determination of tetracycline hydrochloride by HPLC method at their optimum experimental conditions accomplished at the state company of drug industries and medical appliance in Nineveh, Iraq (NDI), and comparison with our present method (fourth order derivative) indicates that the fourth order derivative method is of a very good recovery percent as shown in (Table 14).

Table 14: Comparison between the standard HPLC method and the present method for the determination of tetracycline hydrochloride in pharmaceutical formulation.

\begin{tabular}{|l|c|c|}
\hline \multirow{2}{*}{ pharmaceutical preparation } & \multicolumn{2}{|c|}{ Recovery \% } \\
\cline { 2 - 3 } & Present method & Standard method \\
\hline Tetracycline-HCl & 100.2 & 101.8 \\
250mg /capsule & & \\
S.D.I Iraq & & \\
\hline
\end{tabular}

*Average of three determinations 


\section{REFERENCES}

Abdel Khalek, M.B.; Mahrous, M.S. (1983). Spectrophotomatric determination of tetracycline and cephalosporins with ammonium vanadat. Talanta, 30(10), 792-794.

Al-Ramadani, M.O.(2007). Development of spectrophotometric method for determination of thymol, dapsone and tetracycline using diazotization coupling reaction. M. Sc., Thesis, Mosul University, 74-96.

Bhattacharya, B. D. (2003). An evaluation of current cholera treatment. Expert opin. pharmacother, 4(2),141-146.

Bonta, D.; Marghitas, O.; Dezmirean, B.; Molse, B.; Magtlear, O. (2007). Optimization of HPLC method for quantifuing tetracycline residue in hony. J. Animal Sci. and Biotechnologies, 64(1).

British pharmacopoiea (2009). "On CD-ROM". 5th edn., system simulation Ltd, The Stationary office, London.

Fritz, P.A.; Zuo, (2007). Simultaneus determination of tetracycline, oxytetracycline and 4epitetracycline in milk by high -performance liquid chromatography. food Chemistry, 105(3),1297-1301.

Ibrahim, N.G. (2001). Voltammetric studies of interaction of nogalamycin anititumer drug with DNA. Analytica Chimica ACTA, 443(1), 63-72.

Jeon, P. (2008). Quantitative detection of tetracycline residues in honey by a simple sensitive immunoassay. Anal. Chem. Acta, 626, 180-185.

Katzung, B.G.; Master, S.B.; Trevor, A.J. (2009). "Basic and Clinical Pharmacology". 11th ed. pp.796-799.

Masawat, S.; Liawruangrath, S.; Upalee (2008). Spectrophotometric Flow-injection analysis assay of tetracycline antibiotic using a dual light-emitting diode based detector. Mj. Int. J. Sci. Tech., 2(01), 201-209.

Moats, A.A.; Khan. (1996). Rapid determination of tetracycline antibitics in milk and tissues using ion paring high performance liquid chromatography. American Chem. Soc., 636, 85-96.

Morelli, P.P. (1985). Spectrophotomatric determination of tetracycline in pure form and pharmaceutical preparations by a molybdenum blue method. J. Anal. Lett., 18(15),1865-1886.

Navigation, A. (2005). "Martin Dell Complete Drug Reference". 34th edn., Pharmaceutical Press, London, pp. 266-269.

Reybroeck, S.O.; Brabander, H.D.; Daeseleire, E. (2007). Validation of the tetra sensor honey test kit for the screening of tetracycline in honey. J. Agric. food Chem., 55, 359-8364.

Ruengsitagoon, O.P. (2008). A rapid flow injection spectrophotometric analysis for tetracycline. chloro tetracycline or oxytetracycline. J. Food and drug Analysis.16(6), 16-21.

Sastry, K.R.; Prasad, M.M.K. (1996). Spectrophotometric determination of drug in pharmaceutical formulations with N-bromosuccinimide and celestine blue. Mikrochimica Acta, 122(1-2), 7786.

Sczesny, M.A.; Nau, H.N.; Hamscher, G. (2003). Residue analysis of tetracycline their metabolites in eggs and in the environment by HPLC coupled with crobiologica assay and tandem massspectrometry. J. Agric. Food Chem., 51(3), 697-701. 